\title{
Tall P waves associated with severe hypokalemia and combined electrolyte depletion.
}

$\operatorname{AUTHOR}(S):$

Kishimoto, Chiharu; Tamaru, Kosaku; Kuwahara, Hiroyasu

\section{CITATION:}

Kishimoto, Chiharu ... [et al]. Tall P waves associated with severe hypokalemia and combined electrolyte depletion.. Journal of electrocardiology 2014, 47(1): 93-94

\section{ISSUE DATE:}

2014-01

URL:

http://hdl.handle.net/2433/180299

\section{RIGHT:}

(c) 2014 Elsevier Inc.; この論文は出版社版でありません。引用の際には 出版社版をご確認ご利用ください。; This is not the published version. Please cite only the published version. 


\section{Tall P Waves Associated With Severe Hypokalemia And Combined Electrolyte Depletion}

Chiharu Kishimoto, MD, PhD; Kosaku Tamaru, $\mathrm{PhD}^{*}$, Hiroyasu Kuwahara, $\mathrm{MD}, \mathrm{PhD} *$

Department of Cardiovascular Medicine, Graduate School of Medicine, Kyoto University, 54 Kawara-cho, Shogoin, Sakyo-ku, Kyoto 606-8507, Japan

Internal Medicine, Seika-cho Hospital*

Total word count: 1071 words

Keywords: tall P wave(s); pseudo P pulmonale; hypokalemia; ECG; electrolyte(s)

Address for Correspondence : $\quad$ Chiharu Kishimoto, $\mathrm{MD}, \mathrm{PhD}$

Department of Cardiovascular Medicine,

Graduate School of Medicine, Kyoto University,

54 Kawara-cho, Shogoin, Sakyo-ku,

Kyoto 606-8507, Japan

Tel: (81)075-751-3197

Fax: (81)075-751-4281

E-mail: kkishi@kuhp.kyoto-u.ac.jp 
Kishimoto et al. 2

\begin{abstract}
A 32-year-old woman with anorexia nervosa showing tall $\mathrm{P}$ waves on electrocardiogram (ECG) was reported. Her ECG showed tall $\mathrm{P}$ waves $(5.5 \mathrm{~mm}$ in voltage, lead II ) at $2.2 \mathrm{mEq} / \mathrm{L}$ of serum potassium. After the treatment, $\mathrm{P}$ waves decreased in voltage with the normalization of serum potassium. Tall $\mathrm{P}$ waves may be considered to be the so-called pseudo $\mathrm{P}$ pulmonale, and added to the criteria of hypokalemia on ECG.
\end{abstract}

\title{
Keywords
}

Tall P wave, pseudo P pulmonale, hypokalemia, ECG, electrolytes

\section{Introduction}

It is well known that electrolytes disturbance causes ECG changes and that hyperkalemia leads to low $\mathrm{P}$ waves and tall $\mathrm{T}$ waves on ECG. However, little has been reported on the morphology of $\mathrm{P}$ waves in hypokalemia [1]. In this report, the patient with severe hypokalemia and combined electrolyte depletion from anorexia nervosa showing tall $\mathrm{P}$ waves on ECG was reported.

\section{Case report}

A 32-year-old woman with anorexia nervosa was transferred to our hospital because of general malaise, loss of appetite, and malnutrition. She had no past history of taking any particular drugs. On admission, height was $158.0 \mathrm{~cm}$, body weight $26.0 \mathrm{~kg}$, and blood pressure $88 / 50 \mathrm{mmHg}$ with a pulse rate of $84 \mathrm{bpm}$. Her ECG showed normal sinus rhythm with tall $\mathrm{P}$ waves (arrows, $5.5 \mathrm{~mm}$ in voltage, lead II), ST-segment depression, and prominent U waves [Figure, Panel (a)]. Serum potassium was low and $2.2 \mathrm{mEq} / \mathrm{L}(\mathrm{Na}, 127 \mathrm{mEq} / \mathrm{L} ; \mathrm{Cl}, 81 \mathrm{mEq} / \mathrm{L}$ ). Serum calcium was $8.4 \mathrm{mg} / \mathrm{dL}$ (normal value, $8.6 \sim 10.1 \mathrm{mg} / \mathrm{dL}$ ). Serum magnesium was $1.1 \mathrm{mg} / \mathrm{dL}$ (normal value, 1.8 2.6 
Kishimoto et al. 3

$\mathrm{mg} / \mathrm{dL}$ ), and serum phosphorus $1.8 \mathrm{mg} / \mathrm{dL}$ (normal value, $2.5 \sim 4.6 \mathrm{mg} / \mathrm{dL}$ ). Total protein was $6.2 \mathrm{mg} / \mathrm{dL}$, glutamic oxaloacetic transaminase (GOT) $32 \mathrm{U} / \mathrm{L}$, glutamic pyruvic transaminase (GPT) $21 \mathrm{U} / \mathrm{L}$, creatine kinase $(\mathrm{CK}) 40 \mathrm{U} / \mathrm{L}$, total cholesterol 175mg/dL, serum glucose $107 \mathrm{mg} / \mathrm{dl}$, and blood urea nitrogen (BUN) 11mg/dL. There were no signs of congestive heart failure or pulmonary embolism on physical examination. The left and right ventricular wall motions and the size of both atria were normal on echocardiography. Right ventricular hypertrophy was not present. The chest X-ray revealed $34 \%$ of cardio-thoracic ratio with a normal cardiac silhouette. After oral supplement of potassium tablets and food intake, tall $\mathrm{P}$ waves decreased in voltage (3 $\mathrm{mm}$, lead II ), but ST-segment depression and prominent U waves remained on the 4th hospital day (K, $2.5 \mathrm{mEq} / \mathrm{L}$; Na, $129 \mathrm{mEq} / \mathrm{L} ; \mathrm{Cl}, 85 \mathrm{mEq} / \mathrm{L})[$ Figure, Panel (b)]. On the 7th day, $\mathrm{P}$ waves were almost normal, and $\mathrm{U}$ waves were not obvious $(\mathrm{K}, 3.5 \mathrm{mEq} / \mathrm{L}$; Na, $141 \mathrm{mEq} / \mathrm{L} ; \mathrm{Cl}, 99 \mathrm{mEq} / \mathrm{L})[$ Figure, Panel (c)].

\section{Discussion}

It is well known that there are many ECG changes in patients with hypokalemia; QT interval prolongation, ST-segment depression, $\mathrm{T}$ wave inversion, and prominent $\mathrm{U}$ waves [1,2]. However, little has been reported on the morphology of $\mathrm{P}$ waves in hypokalemia. Customarily termed P pulmonale has been generally accepted to represent right atrial enlargement. In our present case, however, acute right or left atrial enlargement was unlikely on the basis of the X-ray findings, echocardiograms and other clinical observations. On the other hand, it is also known that a $\mathrm{P}$ pulmonale pattern could occasionally be observed in patients with hypokalemia and that $\mathrm{P}$ pulmonale is transient and concomitant [3-7]. In case of hypokalemia, action potential activities are easy to occur. As the mode of opening of ion channels depends upon the electrical 
Kishimoto et al. 4

difference across the cell membrane, sodium ion channel is easy to open as low as the intracellular electrical activities are low. Therefore, in case of hypokalemia, sodium ion is easy to enter the cell for the action potential to easily rise up. As a result, the amplitude of $\mathrm{P}$ waves is getting higher than before [8]. As shown in this patient, $\mathrm{P}$ wave amplitude is sensitive to changes of serum potassium levels. In this case, just a small amount of potassium supplementation $(2.2 \mathrm{mEq} / \mathrm{L}$ to $2.5 \mathrm{mEq} / \mathrm{L})$ dramatically decreased P wave amplitude, but QRS amplitude was not apparently changed; then a further increase in potassium concentration $(2.5 \mathrm{mEq} / \mathrm{L}$ to $3.5 \mathrm{mEq} / \mathrm{L})$ dramatically decreased QRS amplitude. If this can be applied in general, one could speculate that increase in QRS amplitude may be a relatively early sign of hypokalemia, and that increase in P wave amplitude may be a sign of severe hypokalemia. The decrease in QRS amplitude on the 7th day when the potassium level is $3.5 \mathrm{mEq} / \mathrm{L}$ could be partly explained by the difference in action potential amplitude of the atria and ventricles. Although alternative explanations except for hypokalemia, e.g. reduced skin thickness due to anorexia might be considered, hypokalemia and combined electrolyte depletion should be considered in patients having tall $\mathrm{P}$ waves on ECG.

Informed consent was obtained from the patient.

\section{References}

1) Akita M, Kuwahara $M$, Tsubone $H$, Sugano $S$. ECG changes during furosemide-induced hypokalemia in the rat. J Electrocardiol 1998; 31:45.

2) Charles F: Electrocardiography. p.108. In Braunwald E (ed) Heart Disease. A Textbook of Cardiovascular Medicine. 5th Ed. Saunders, Philadelphia, 1997

3) Khan MU, Patel AG, Wilbur SL, Khan IA. Electrocardiographic changes in 
combined electrolyte depletion. Int J Cardiol 2007; 116:276.

4) Weaver WF, Burchell HB. Serum potassium and the electrocardiogram in hypokalemia. Circulation 1960; 21:505.

5) Kitamoto O, Hiraishi K, Takigami T, Saito M, Shimizu N. Electrocardiographic findings in cholera El Tor patients. Bull World Health Organ 1967; 37:787.

6) Ishikawa K, Tateno M. Alternans of the repolarization wave in a case of hypochloremic alkalosis with hypopotassemia. J Electrocardiol 1976; 9:75.

7) Chou TC, Helm RA. The pseudo P pulmonale. Circulation 1965; 32:96.

8) Kanai M, Kanai I: Kanai's Manual of Clinical Laboratory Medicine, 30th Ed. Kanehara, Tokyo, 1998 (Japanese)

\section{Figure legends}

Serial ECG changes. Tall P waves [arrows, Panel (a)] and prolonged QT(U) intervals (560 $\mathrm{msec})$ were seen at severe hypokalemia. P wave amplitude was gradually decreased [Panels (b), (c)] with the normalization of the serum potassium level. However, prolonged QT(U) intervals [540 msec, Panel (b); $520 \mathrm{msec}$, panel (c)] were still seen. 
(a)
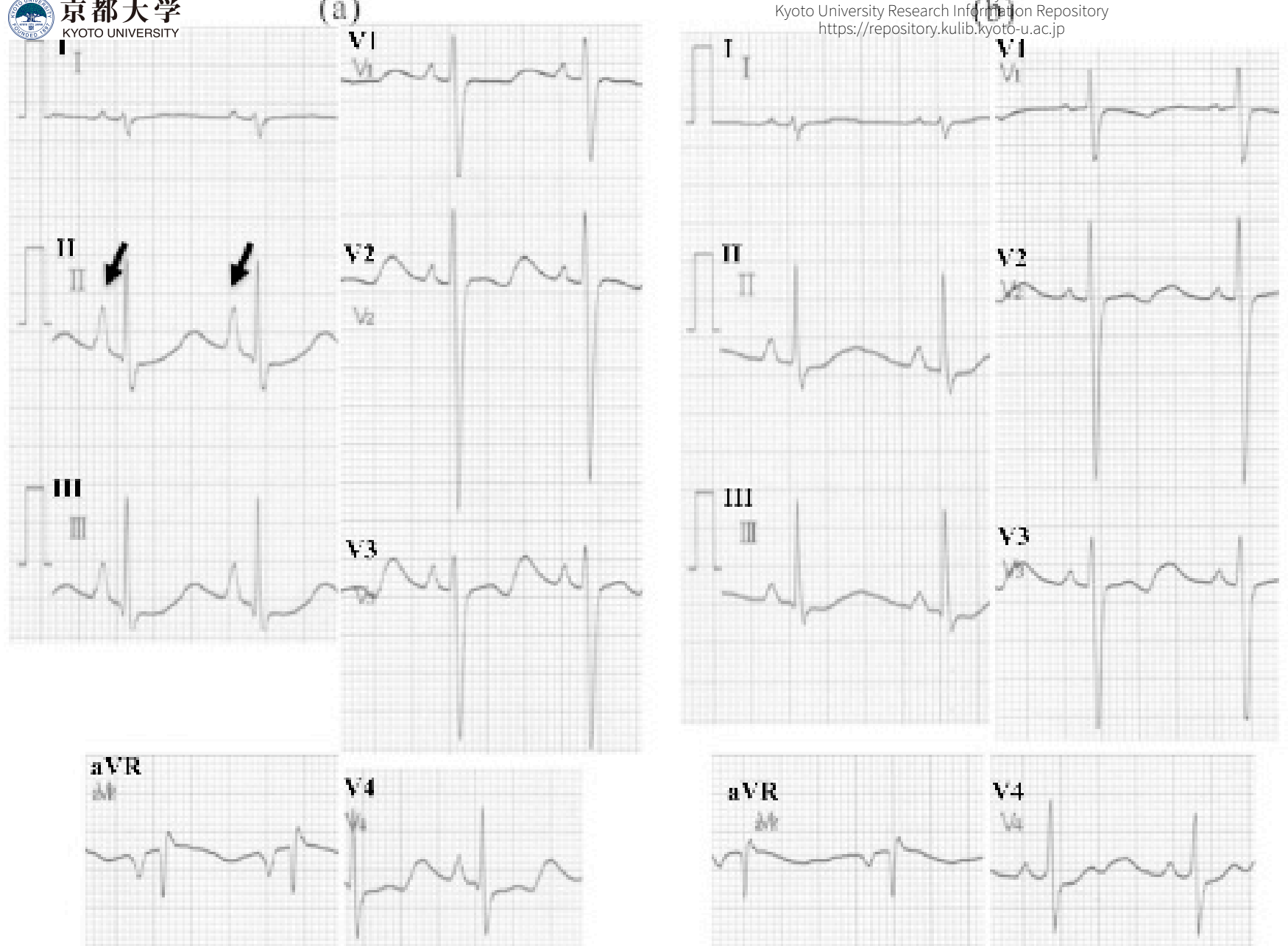

aVL
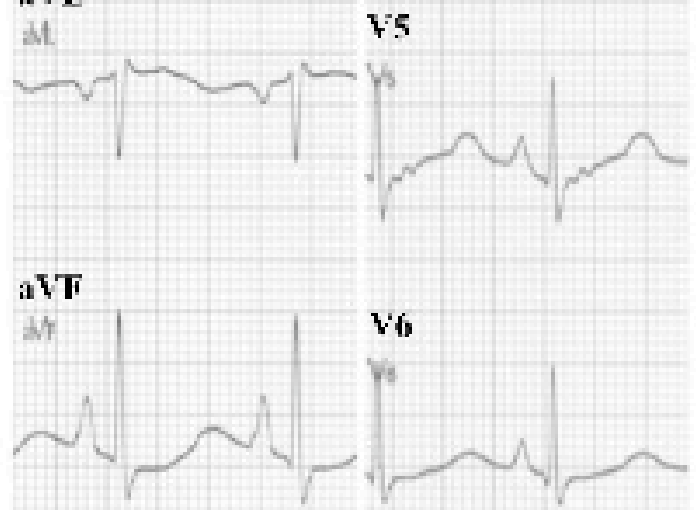
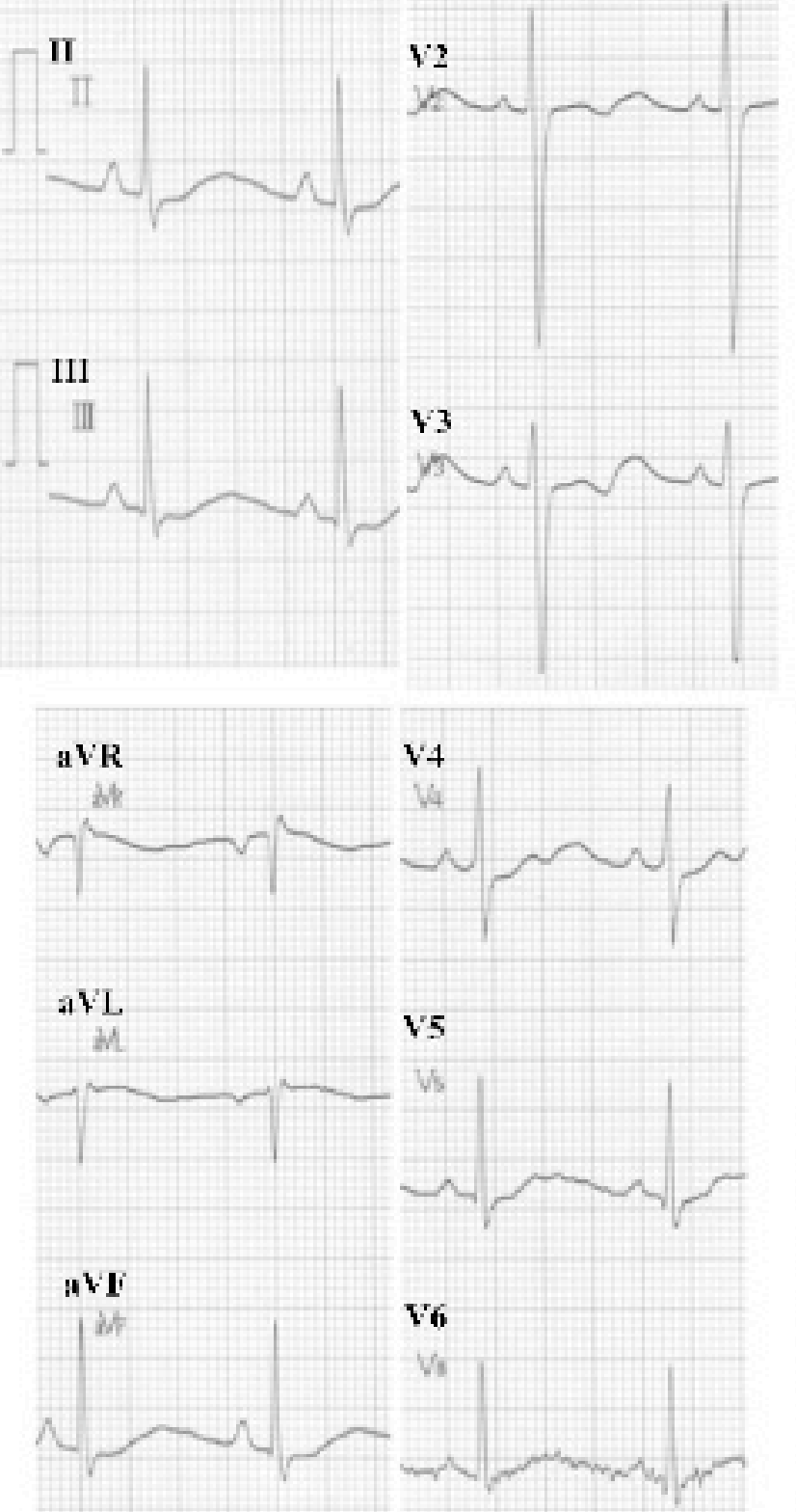

(c)
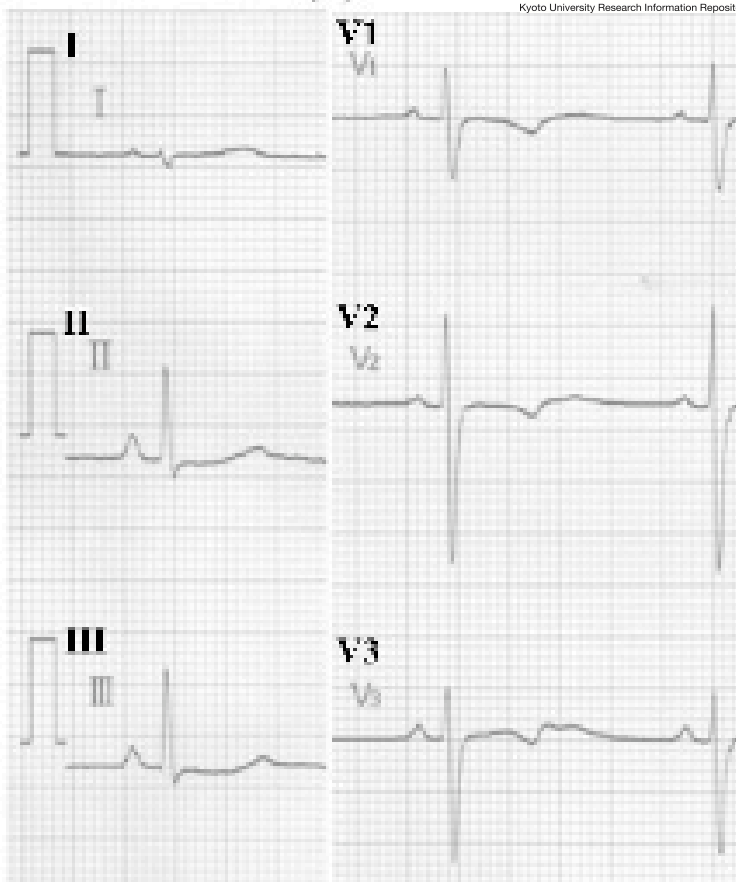

aYR

its

v4

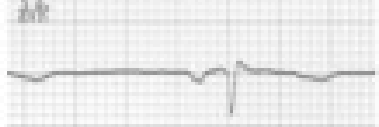

aVL

A. 15

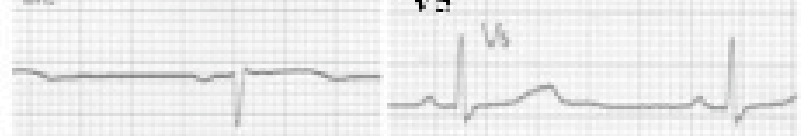

aV'F

at

if

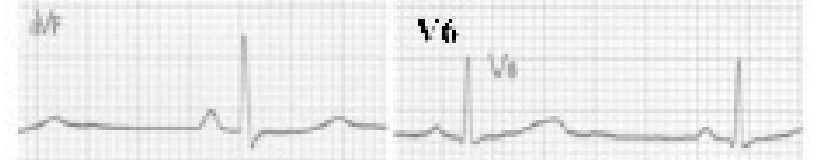

